\title{
Analysis of Suitability and Carrying Capacity of Mangrove Ecotourism in Sedari Village, Karawang District
}

\author{
Wildan Dhya Ulhaq Hidayat ${ }^{1}$, Indah Riyantini ${ }^{2}$, \\ and Wahyuniar Pamungkas ${ }^{2}$ \\ ${ }^{1}$ Student Study Program of Marine Sciences, Faculty of Fisheries and Marine Sciences, \\ University of Padjadjaran \\ ${ }^{2}$ Departement Study Program of Marine Sciences, Faculty of Fisheries and Marine Sciences, \\ University of Padjadjaran
}

Corresponding Author: wildandhya15@gmail.com

\section{ARTICLE INFO}

Received

28 November 2019

Accepted

28 January 2020

Available online

31 March 2020

\section{ABSTRACT}

Mangrove nature tourism Sedari Village is an ecotourism location that has the potential to be developed with natural resources that are still awake and an area of mangrove forests around 49.20 Ha. However, in its management, it still does not pay attention to the principles of ecotourism regarding the suitability and carrying capacity for ecotourism. The purpose of this study is to determine the potential in the mangrove nature tourism Sedari Village and assess the suitability and carrying capacity. The method used in this research is survey method and descriptive - quantitative analysis. The results obtained in the mangrove nature tourism Sedari Village there are 4 types of mangroves, namely $R$. mucronata, $R$. stylosa, $S$. alba and A. marina with a mangrove density of 2.055 ind / ha then found 4 types of biota and 2 species namely mullet fish, milkfish, mangrove crabs, little egrets and monitor lizards. For the tourism suitability index value obtained $73 \%$ which is included in both the category and the physical carrying capacity obtained 32,800 people / day, the real carrying capacity is 25,047 people / day and the ecological carrying capacity is 26.65 ha. ecological carrying capacity for bridge tracking tourism activities obtained by 55 people / ha and bird watching tourism activities obtained by 165 people / ha.

Keywords: mangrove, ecotourism suitability, ecotourism carrying capacity 


\section{INTRODUCTION}

Mangrove forests are typical ecosystems in coastal areas that have natural beauty and the environment in the form of components of the ecosystem consisting of vegetation, biota or organisms, wildlife and the surrounding environment. According to the Department of Forestry (1996), mangrove ecosystems have three functions such as physical functions, namely being able to protect coastlines from abrasion, biological functions, namely as a place to find food and breed for fish, shrimp, shellfish, crabs, and other marine biota, and economic functions namely as a place for aquaculture ponds, places for taking wood and tourist attractions. This dewasi, the pressure of decline in mangrove ecosystems continues to occur. Based on a press release from the Ministry of Environment and Forestry, many stated that in 2018 Indonesian mangroves suffered damage of 1.81 ha (Republika.co.id 01-01-2018). The decline in mangrove forests is one of them caused by anthropogenic factors or human activities (Amal, 2018). Utilization of mangrove ecosystems should be able to pay attention to the protection of mangrove

http://ojs.unud.ac.id/index.php/eot ecosystems from damage so that their utilization can be sustainable.

Ecotourism is one form of utilization that emphasizes the principle of conservation. Ecotourism itself is a form of tourism to natural areas which is carried out with the aim of conserving the environment and the welfare of the local community (Fandeli, 2000).

Mangrove nature tourism in Sedari Village is a mangrove ecotourism located in Karawang Regency which has an area of about 49.20 ha of mangrove forest with a beautiful mangrove forest landscape. The condition of mangrove forests in the natural tourism of Sedari mangroves is still well maintained and organisms that live in association with mangroves can still be found such as crustaceans, reptiles and birds.

Mangrove nature tourism in the new village of Sedari stands and in its use is still less than optimal. According to Wati \& Idajati (2017), changes in conservation areas becoming ecotourism results in a decrease in environmental quality. The decline in the quality of the ecotourism environment is caused by management that does not pay attention to the suitability and carrying capacity of the 
region (Hermawan, 2015) in (Wati \& Idajati, 2017). Therefore, research is needed regarding the suitability and carrying capacity of mangrove ecotourism in Sedari Village so that its management does not cause damage to the mangrove ecosystem itself.

This study aims to determine what the potential contained in the mangrove ecotourism Sedari Village and assess the suitability and carrying capacity.

\section{METHOD}

This research was conducted in Sedari Village, Karawang Regency, geographically located at $5^{\circ} 59 ' 38.41$ "S and $107 \circ 18^{\prime} 0.85^{\prime \prime} \mathrm{E}$ (figure 1). Determination of the station is done by purposive sampling method as many as 4 station points. The determination of the station is based on the consideration of the thickness of mangroves at each station.
The method used in this research is survey method and descriptive - quantitative analysis.

The tools used for data collection in the field are roll meter, rapia rope, meter, Global Positioning System (GPS), camera stationery and mangrove identification book and natural biota.

\section{Research procedure}

Preparation

Field observations, station determination and literature studies regarding the condition of the research location.

\section{Data retrieval}

The data taken is mangrove thickness data, the method used is to be measured directly using a roll meter at a predetermined station. Mangrove type and density data are taken using the quadrant transect method. For biota object data taken using the direct observation method. 


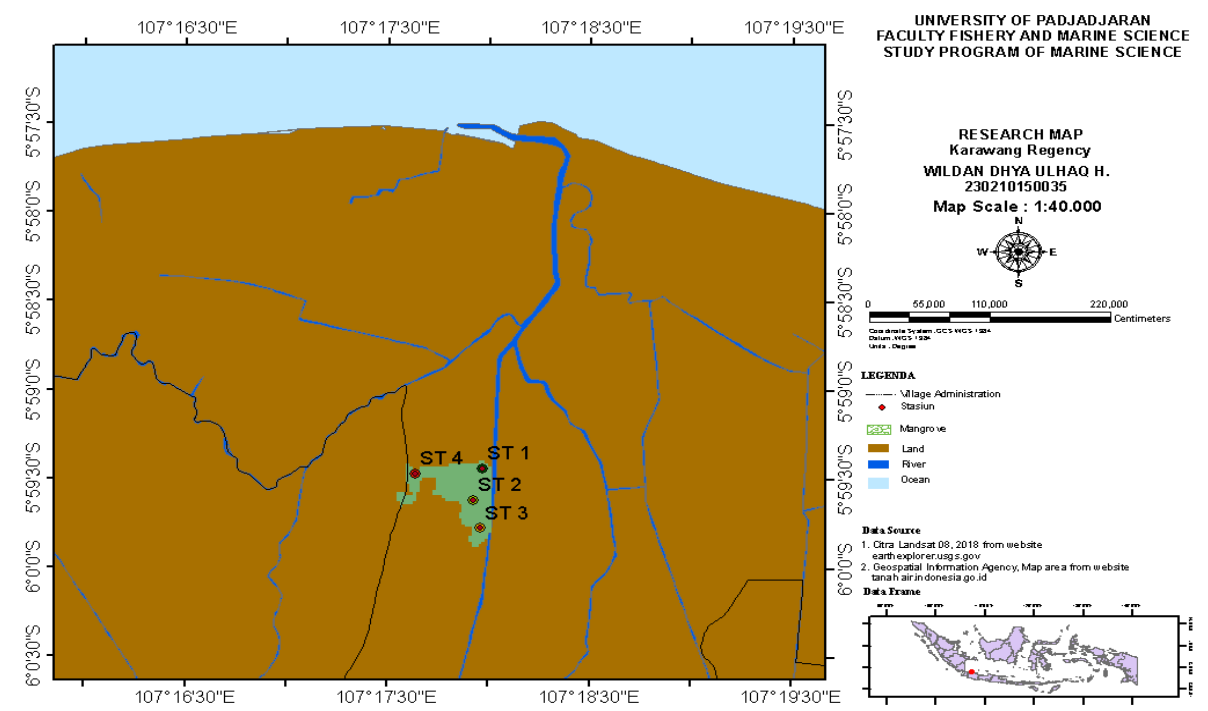

Picture 1. Research Location Map

\section{Data processing}

Mangrove density (Onrizal, 2008)

Density $(\mathrm{K})=$

Number of individuals of a type

The entire plot area

Relative Density $(\mathrm{KR})=$

$$
\frac{\text { density of a type }}{\text { density of all types }} \times 100 \%
$$

The diversity of species of shannon wienner (Onrizal, 2008)

$$
\mathrm{H}^{\prime}=-\sum p \text { iln }(p \mathrm{i})
$$

Information:

$\mathrm{H}^{\prime}$ = Type diversity index

$n \mathrm{i}=$ Number of Individual Type $\mathrm{i}$
$P \mathrm{i}=n i / N$

$N=$ Total Individuals of All Types

\section{Data analysis}

\section{Ecotourism Suitability Matrix}

Calculation of suitability of Ecotourism based on the formula Yulianda (2007), namely:

$$
\mathrm{IKW}=\sum\left(N_{i} / N_{\text {Max }}\right) \times 100 \%
$$

Description :

IKW = Tourism Suitability Index;

$\mathrm{Ni}=$ keI parameter value (weight $\mathrm{x}$ score);

Nmax $=$ Maximum value of a category 


\section{Carrying Capacity of Mangrove}

\section{Ecotourism}

Analysis of mangrove ecotourism carrying capacity includes physical carrying capacity, real carrying capacity and ecological carrying capacity (Douglass, 1975).

\section{Physical carrying capacity (PCC)}

$$
\mathrm{PCC}=\mathrm{Ax}_{\underline{-}}{ }^{1} \mathrm{x} \mathrm{Rf}
$$

B
Information :

$\mathrm{A}=$ Area used for tourism

$\mathrm{B}=$ Area required by a tourist to travel

$\mathrm{Rf}=$ rotation factor $(\mathrm{Rf})$ is the number of daily visits allowed to a location formulated by the formula

\section{$\mathrm{Rf}=$ visiting period}

long visiting

Table 1. Ecotourism Suitability Matrix

\begin{tabular}{|c|c|c|c|c|c|c|c|c|c|c|}
\hline No & Parameter & Weight & $\begin{array}{c}\text { S1 } \\
\text { Cateory }\end{array}$ & Score & $\begin{array}{c}\text { S2 } \\
\text { Category }\end{array}$ & Score & $\begin{array}{c}\text { S3 } \\
\text { Category }\end{array}$ & Score & $\begin{array}{c}\mathrm{N} \\
\text { Category }\end{array}$ & Score \\
\hline 1 & $\begin{array}{l}\text { Mangrove } \\
\text { Thickness }\end{array}$ & 5 & $>500$ & 4 & $>200-500$ & 3 & $50-200$ & 2 & $>50$ & 1 \\
\hline & (m) & 4 & $>15-20$ & 4 & $>10-15$ & 3 & $5-10$ & 2 & $<5$ & 1 \\
\hline $\begin{array}{l}2 \\
3\end{array}$ & $\begin{array}{c}\text { Mangrove } \\
\text { Density }\end{array}$ & 4 & $>5$ & 4 & $3-5$ & 3 & $1-2$ & 2 & 0 & 1 \\
\hline & $\left(100 \mathrm{~m}^{2}\right)$ & & $>4$ & 4 & 3 & 3 & 2 & 2 & 1 & 1 \\
\hline 4 & $\begin{array}{c}\text { Mangrove } \\
\text { Type } \\
\text { Biota } \\
\text { Objects }\end{array}$ & 3 & Species & & Species & & Species & & Species & \\
\hline
\end{tabular}




\section{Real carrying capacity ( $\mathrm{RCC})$}

$$
\mathrm{RCC}=\mathrm{PCC} \times \frac{100-C \mathrm{f} 1}{100} \times \frac{100-C \mathrm{f} 2}{100}
$$

Information:

$\mathrm{RCC}=$ real carrying capacity

PCC $=$ physical carrying capacity

$\mathrm{Cf}=$ Correction Factor

\section{Ecological carrying capacity}

$$
\mathrm{AR}=\frac{\mathrm{D} \times \mathrm{A}}{\mathrm{CD} \times \mathrm{Tf} \times 43560}
$$

Information :

$\mathrm{AR}=$ Area required for travel

$\mathrm{D}=$ Number of tourists

$A=$ area needs of each tourist

$\mathrm{CD}=$ Number of days used for traveling

$\mathrm{Tf}=$ recovery factor

$43,560=$ Constants

\section{RESULTS AND DISCUSSION}

\section{Mangrove Density}

The density of mangroves in mangrove nature tourism in Sedari Village is presented in table 2 .
Table 2. Mangrove Density

\begin{tabular}{lcc}
\hline & & Tree \\
Station & Type & $\mathrm{K}$ (ind/ha)
\end{tabular}

\begin{tabular}{lll}
\hline 1 & $\frac{\text { R.mucronata }}{\text { S.alba }}$ & 400 \\
2 & $\frac{2}{\text { R.mucronata }}$ & 855 \\
3 & $\frac{2}{\text { S.alba }}$ & 480 \\
& $\frac{\text { R.stylosa }}{\text { S.alba }}$ & \\
4 & $\frac{\text { R.marina }}{\text { R.mucronata }}$ & 320 \\
& $\frac{2}{\text { A.marina }}$ & \\
\hline & Totmucronata & 2.055 \\
\hline
\end{tabular}

Based on the table above the types of mangroves found in mangrove nature tourism in Sedari Village obtained 4 types namely Rhizopora mucronata, Rhizopora stylosa, Sonneratia alba and Avicenia marina With the diversity value of mangrove species obtained $\mathrm{H}$ ' 1.1 which is included in the low category.

The density of mangroves in the natural tourism of the village of Sedari obtained 2,055 ind / ha. Based on the standard and mangrove damage of the Ministry of Environment No. 201 of 2004 the density of mangroves in the natural tourism of the Mangrove Village of Sedari is included in good condition with a very dense density. 
At each observation station there is a difference in density which shows the level of adaptation patterns and human influence on the mangrove ecosystem. In the mangrove nature tourism in the Village Sedari mangrove species Rhizopora mucronata and Rhizopora stylosa are found in the area near the river. This is according to Noor et al (2006), that Rhizopora spp grows in groups, near river embankments and river mouths. Sonneratia alba mangroves are also found near streams. According to Sukardjo \& Sukristijono (1984). Gonneratia alba colonized and was found near the mouths of rivers or near large rivers. Then the types of types of Avicenia marina

\section{Biota Objects}

Objects of biota in the mangrove nature tourism of Sedari Village were found 4 species and 2 species of biota namely mangrove crab (Scylla serrata), small egret (Egretta garzetta) monitor lizard (Varanus salvator) and fish species found 2 species namely mullet fish (Valamugil engeli), fish banding (Chanoschanos),

Mangrove crabs are often found under mangrove roots in small holes. As According to Rahayu et al (2017) mangrove crabs like mangrove vegetation which has a strong mangrove root system.
Mangrove crabs will form small holes under the roots of mangroves as a shelter and find food.

Mulletfish and milkfish are commonly found in mangrove areas that have water-submerged substrates which are former semi-intensive pond management areas. Mullet fish is one of the inhabitants of mangrove waters (Puteri et al 2017). Huang et al (2016) in Puteri et al (2017) further explained that fish from the Mugilidae family have a distribution in the mangrove area and these fish can live in a wide range of salinity because they can live in freshwater, brackish water and the sea. The appearance of milkfish in the mangrove area is thought to be a result of the remaining ponds.

The small egret bird in the mangrove nature tourism in Sedari Village was found in the twig of the mangrove tree with a very large number. Elfidasari and Junardi (2005), the abundance of birds in an area is caused by the availability of food. Mangrove nature tourism in Sedari Village has an area that is close to the area of fish ponds so people are not surprised that many herons are found in the area.

Lizards are also found in mangrove areas with water-submerged substrates. The emergence of monitor lizards is thought to originate from a river that is 
adjacent to tourism the mangrove nature of Sedari Village. As According to Byer (1999) in Gumilang (2001), monitor lizards are aquatic animals that can be found in water sources such as along rivers, swamps or mangrove debts. Iyai and Pattiselano (2005) further explained that monitor lizards perform in swamp forests because habitat types for monitor lizards are easier to find prey.

\section{Conformity Analysis of Mangrove Nature Tourism}

The value of the suitability index of mangrove nature tourism in Sedari Village can be seen in table 3.

Table 3. Value of IKW Mangrove Nature Tourism in Sedari Village

\begin{tabular}{|c|c|c|c|}
\hline No & $\begin{array}{l}\text { Research } \\
\text { Sites }\end{array}$ & IKW & Information \\
\hline 1 & Station 1 & $\begin{array}{l}79 \\
\%\end{array}$ & $\begin{array}{l}\mathrm{S} 2 \\
\text { (appropriate) }\end{array}$ \\
\hline 2 & Station 2 & $\begin{array}{l}70 \\
\%\end{array}$ & $\begin{array}{l}\text { S2 } \\
\text { (appropriate) }\end{array}$ \\
\hline 3 & Station 3 & $\begin{array}{l}76 \\
\%\end{array}$ & $\begin{array}{l}\text { S2 } \\
\text { (appropriate) }\end{array}$ \\
\hline 4 & Station 4 & $\begin{array}{l}68 \\
\%\end{array}$ & $\begin{array}{l}\text { S2 } \\
\text { (appropriate) }\end{array}$ \\
\hline & Average & $73 \%$ & $\begin{array}{l}\text { S2 } \\
\text { (appropriate) }\end{array}$ \\
\hline
\end{tabular}

Based on the above table the value of tourism suitability index obtained from four stations shows that the mangrove nature tourism of Sedari Village is included in the category according to the
IKW value of $73 \%$. These values indicate that the mangrove nature tourism of Sedari Village can be developed with the potential of its resources, but in its management must pay attention to several things such as diversity of mangrove species, diversity of biota species and thickness of mangove which has a low score value. Mangrove thickness is an important thing that must be considered because it has a litter-producing role for biota so that when mangrove thickness is high, the number and type of biota is also high.

\section{Carrying Capacity of Mangrove Village Sedari Nature Tourism}

Physical carrying capacity

Physical carrying capacity is a calculation to find out the number of visitors to get physical comfort while traveling. According to Douglass (1975) the area required for each visitor to travel is $60 \mathrm{~m} 2$. So that the physical carrying capacity in the mangrove nature tourism of Sedari Village is 32,865 people / day.

\section{Real carrying capacity}

Real carrying capacity aims to determine the carrying capacity in real terms by using two correction factors, namely rainfall and diversity of mangrove species. These two correction factors are used because they are related to the level 
of tourist visits to mangrove nature tourism in Sedari Village.

The real carrying capacity in mangrove nature tourism in Sedari Village obtained 25,124 people / day. The results of the real carrying capacity when compared to physical carrying capacity are still smaller or in other words that mangrove nature tourism in Sedari Village can still accommodate tourists who visit.

\section{Ecological carrying capacity}

Ecological carrying capacity is a calculation to determine the area of ecological tourist areas that can recover naturally. So by knowing the value of its ecological carrying capacity, mangrove ecosystems in the natural tourism area of mangroves in Sedari Village can be avoided from damage due to tourism activities.

The ecological carrying capacity of 26.65 ha. Mangrove nature tourism in Sedari Village, there are two tourism activities that can be calculated ecological carrying capacity, namely tracking bridges with an area of 1 ha and carrying capacity of 55 people / ha, then bird watching with an area of 3.35 ha and ecological carrying capacity of 165 people / ha.

\section{CONCLUSIONS AND SUGGESTIONS}

\section{Conclusion}

Ecotourism potential found in mangrove nature tourism in Sedari Village is 4 types of mangroves including Rhizopora mucronata, Rhizopora stylosa, Sonneratia alba and Avicenia marina with a total vegetation density of 2,055 ha. In the mangrove nature tourism area, Sedari Village found 4 species and 2 species of biota, namely mangrove crab (Scylla serrata), little egret (Egretta garzetta), monitor lizard (Varanus salvator) and fish species found 2 species namely mullet fish (Valamugil engeli), fish milkfish (Chanos - chnos).

The tourism suitability index in the mangrove nature tourism area of Sedari Village is included in the category according to the IKW value of $73 \%$. While the carrying capacity in the mangrove nature tourism area of Desa Sedari for physical carrying capacity is 32,800 people / day, the real carrying capacity is 25,047 , the ecological carrying capacity is 26.65 ha. In the mangrove nature tourism, Sedari Village has a tourist activity that can be calculated its ecological carrying capacity, namely tracking bridges with a carrying capacity of 55 people / ha and for bird watching with a carrying capacity of 165 people / ha. 


\section{Suggestion}

Based on the results of this study further research can be done on Fauna in the mangrove nature tourism of Sedari Village and in determining the carrying capacity of the correction factors used in this study only using biotic and abiotic factors so that in the future in determining the carrying capacity can include psychological factors of the community and visitors, social and economic factors.

\section{REFERENCES}

Amal, A. (2018). Factor That Influence The Change Of Mangrove Forest in South Sulawesi Indonesia. UNM Geographic Journal, 97-98.

Departemen Kehutanan dan Perkebunan RI. (1996). Manual Silvi kultur Mangrove. Jakarta: PT. Krisna Intervisi Media.

Douglass, W. (1975). Forest Recreation 2. New York: WW Norton and Co. PP.

Efidasari, D., \& Junardi. (2005). Keragaman Burung Air di Kawasan Hutan Mangroe Peniti Kabupaten Pontianak. Biodiversitas, 64-65.

Fandeli, C. (2000). Dasar-Dasar Manajemen Kepariwisataan Alam. Indonesia : Yogyakarta.
Gumilang, R. (2001). Populasi dan Penyebaran Biawak Air Asia (Varanus salvator) di Suaka Margasatwa Pulau Rambut, Jakarta. Bogor: Institut Pertanian Bogor.

Iyai, D. A., \& Pattiselano. (2006). Diversitas dan Ekologis Biawak ( Varanus indicus) di Pulau Pepaya Taman Nasional Teluk Cendrawasih, Irian Jaya Barat. Biodiversitas, 185-186.

Noor, Y. R., Khazli, M., \& Suryadiputra, I. (2006). Panduan Pengenalan Mangrove di Indonesia. Bogor: PHK/WI-IP.

Onrizal. (2008). Teknik Survey dan Analisa Data Sumberdaya Mangrove. 4-7.

Puteri, D., Sitorus, H., \& Muhtadi, A. (2017). Keragaman ikan di Perairan Ekosistem Mangrove Desa Jaring Halus Kabupaten Langkat, Sumatera Utara. Jurnal Jurnal Ilmu Perairan, Pesisir dan Perikanan, 148.

Rahayu, S., Wiryanto, \& Sunarto. (2017). Keanekaragaman Kepiting Biola di Kawasan Mangroe Kabupaten Purworejo Jawa Tengah. EnviroScienteae, 72-74.

Republika.co.id. (2018, $01 \quad$ 10). Kementrian LHK Sebut 1.81 Juta Hektare Mangrove Rusak. Retrieved from https://www.republika.co.id/berita/ ekonomi/makro/18/01/10/p2bu1r38 2-kementerian-lhk-sebut-181-jutahektare-mangrove-rusak 
Sukardjo, \& Sukristijono. (1984).

Ekosistem Mangove. Oseana

Volume IX (4), 102-115.

Wati, M. W., \& Idajati, H. (2017).

Identifikasi Karakteristik

Pengelolaan Ekowisata Mangrove

Wonorejo Berdasarkan Prefensi

Stakeholder. Jurnal Teknik ITS Vol

2, C575-C576.

Yulianda, F. (2007). Ekowisata Bahari Sebagai Alternatif Pemanfaatan Sumberdaya Pesisir Berbasis Konservasi. Makalah Seminar Sains. Bogor: Departemen Manajemen Sumberdaya

Peraiaran. Fakultas Perikanan dan Ilmu Kelautan. 